\title{
The Determinants of Credit Risk under Dual Banking System: Indonesian Experience Based on Bank Specific Variables
}

\author{
Muhammad Nur Faaiz F. Achsani ${ }^{1}$, Salina Kassim² \\ ${ }^{1}$ International Islamic University of Malaysia, Malaysia, mnurfaaiz@ gmail.com \\ ${ }^{2}$ International Islamic University of Malaysia, Malaysia, ksalina@iium.edu.my
}

\begin{abstract}
In Indonesian banking system, conventional banks are operating side by side with Islamic banking in a dual banking system. In terms of the credit risk determinants, Islamic banks should be affected by the different factors as conventional banks. However, the similarity of Islamic banks and the conventional bank in terms of contracts might lead to the opinion the same variables are affecting the performance of Islamic and conventional banks. The objective of the study is to examine and obtain an understanding on how the credit and financing in Indonesian dual banking system responses to changes in bank-specific variables. The main approach to fit the model used in this study is the dynamic panel data. Based on the result of the combined model, there are some independent variables that significantly affect credit risk. Profitability significantly affects credit risk with a negative relationship. While size significantly affects credit risk with a positive relationship. When it comes to the dummy variable, it can be said that the type of bank doesn't play a significant role in determining the credit risk. In other word, there is no difference between Islamic bank and conventional banks in terms of credit risk. To analyze the crisis effect deeper, we compare the result of conventional banking model 2016-2020 and Islamic banking model 2016-2020. There is no independent variable that significantly affect the credit risk in the conventional banking model 2016-2020, three out of four independent variables affect credit risk significantly in the Islamic banking model 2016-2020. This is because conventional banks tend to play safe by avoiding the disbursement of credit and focusing on derivatives. However, this strategy is not suitable for Islamic banking as they are not allowed to do speculative activities. Islamic banking are still focusing on traditional banking activity.
\end{abstract}

Keywords: Conventional banks, credit risk determinants, dynamic panel data, Islamic banks.

\begin{abstract}
Abstrak. Dalam sistem perbankan Indonesia, bank konvensional beroperasi berdampingan dengan perbankan syariah dalam dual banking system. Dalam hal faktor-faktor risiko kredit, bank syariah harus dipengaruhi oleh faktor yang berbeda dengan bank konvensional. Namun, kesamaan bank syariah dan bank konvensional dalam hal kontrak dapat menimbulkan pendapat bahwa variabel yang sama memengaruhi kinerja bank syariah dan konvensional. Tujuan dari penelitian ini adalah untuk mengkaji dan memperoleh pemahaman tentang bagaimana respons kredit dan pembiayaan dalam dual banking system di Indonesia terhadap perubahan variabel spesifik bank. Pendekatan utama agar sesuai dengan model yang digunakan dalam penelitian ini adalah data panel dinamis. Berdasarkan hasil model gabungan, terdapat beberapa variabel independen yang berpengaruh signifikan terhadap risiko kredit. Profitabilitas berpengaruh signifikan terhadap risiko kredit dengan hubungan negatif. Sedangkan size berpengaruh signifikan terhadap risiko kredit dengan hubungan yang positif. Untuk variabel dummy, dapat dikatakan bahwa jenis bank tidak berperan signifikan dalam menentukan risiko kredit. Dengan kata lain, tidak ada perbedaan antara bank syariah dan bank konvensional dalam hal risiko kredit. Untuk menganalisis efek krisis lebih dalam, kami membandingkan hasil model perbankan konvensional 2016-2020 dan model perbankan syariah 2016-2020. Tidak ada variabel independen yang berpengaruh signifikan terhadap risiko kredit pada model perbankan konvensional 2016-2020, tiga dari empat variabel independen berpengaruh signifikan terhadap risiko kredit pada model perbankan syariah 20162020. Hal ini karena bank konvensional cenderung bermain aman dengan menghindari penyaluran kredit dan fokus pada derivatif. Namun, strategi ini tidak cocok untuk perbankan syariah karena tidak diperbolehkan melakukan kegiatan spekulatif. Perbankan syariah masih fokus pada aktivitas perbankan tradisional.
\end{abstract}

Kata kunci: Bank konvensional, bank syariah, data panel dinamis, faktor-faktor risiko kredit. 


\section{INTRODUCTION}

\section{Background}

In Indonesian banking system, conventional banks are operating side by side with Islamic banking in a dual banking system. Islamic banking operation is relatively new in Indonesia compared to the operation of conventional banks. If conventional bank started to exist since the last three decades, Islamic bank only started in 1991 with the establishment of Bank Muamalat. This leads to an advantage for conventional banks in terms of economic of scale which is pictured in the total asset of both types of banks. This affects the capability of the bank to manage the non-performing loan/nonperforming financing. When we use ships at the ocean as the analogy, we can say that conventional banks in Indonesia are like a gigantic ship while Islamic banks in Indonesia are like small ships. When a storm hits the ocean, the gigantic ship will survive better than small ships.

In the COVID-19 pandemic era, conventional banking in Indonesia tends to perform better than Islamic banking counterparts. Islamic banking tends to be more vulnerable to external conditions. It is argued that Islamic banking is in a difficulty to pay off its short-term debt and obligations due to prudence of Islamic banking in channeling funds (Fakhri and Darmawan, 2021). Conventional banking is also viewed to be growing better than Islamic banks in Indonesia during the pandemic period (Candera, Muslimin, and Dina, 2021). Profit and loss sharing modes of financing which are seen as the core values of Islamic finance, are perceived to have higher credit risk by Islamic bankers in Indonesia (Haryono, 2016). According to Khan and Ahmed (2001), Islamic banks from 10 countries recognized that credit risk is the most important risk in profit loss sharing contracts. According to Ariffin, Archer and Karim (2007), Islamic bankers assess credit risk in mudharabah financing and musharakah financing as the primary risk and the second most important risk.

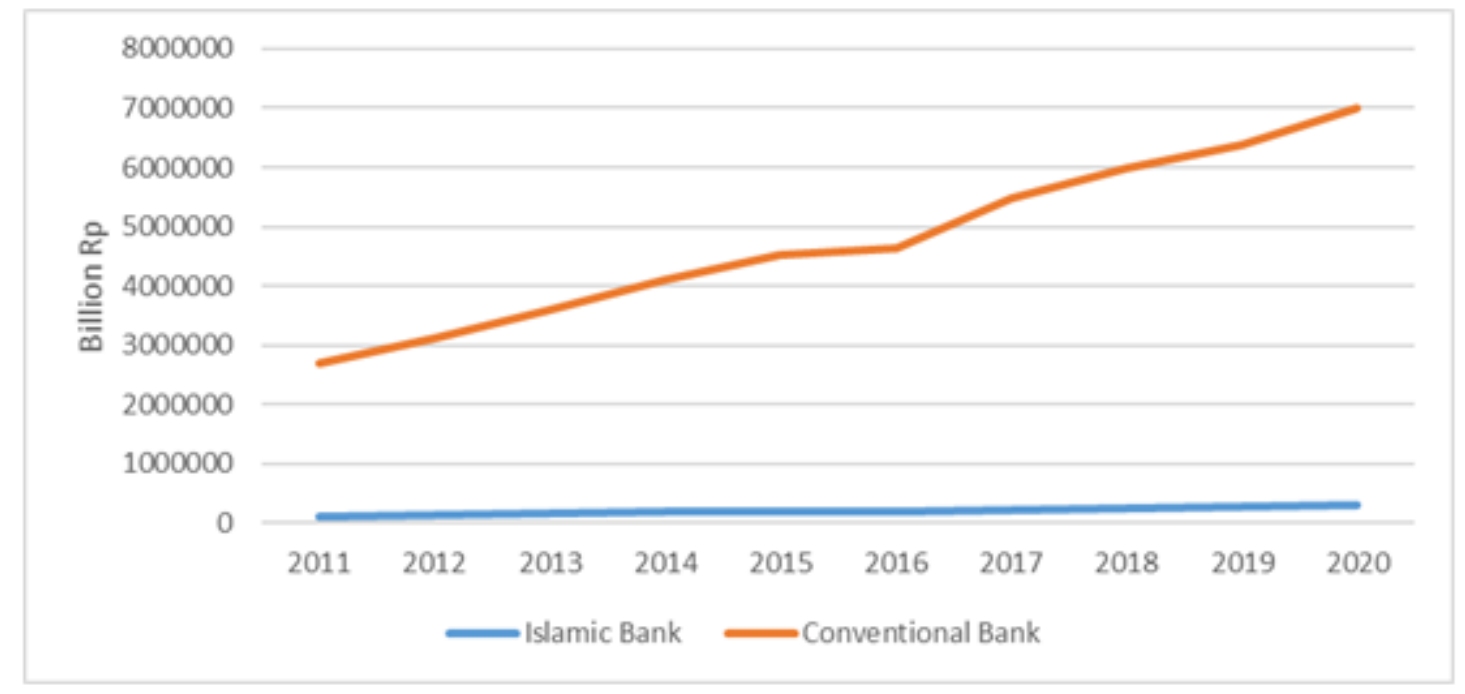

Source: OJK, 2020.

Figure 1 Total asset of Indonesian banks in 2011-2020

On the other side, Islamic banks are argued to be more resilient than conventional banks. According to (Zahra, Ascarya and Huda, 2018), Islamic banking in Indonesia is more stable than conventional banking in facing macro and microeconomic shocks. It is supported by the performance comparison of both types of banking in the financial crisis where Islamic banks were documented in a better position (Majid and Ulina, 2020). This could be due to the just and fair practices of Islamic banking practices which operates in Islamic tenets. It is even argued that Islamic banking would have resisted the sub-prime crisis leading to global economic recession because the very establishing spirit of Islamic finance is anti-speculations (Masud , 2009). 
In terms of the credit risk determinants, Islamic banks should be affected by the different factors as conventional banks. Specific shariah compliant values derive the operation of Islamic banks which should differ the credit risk determinants. However, the similarity of Islamic banks and the conventional bank in terms of contracts might lead to the opinion the same variables are affecting the performance of Islamic and conventional banks (Zarrouk, Jedida and Moualhi, 2016). Numerous studies tried to analyze topic with different conclusions as the result. As far as the author knows, there is no study that compares the credit risk of Islamic banks and conventional banks in Indonesia with dynamic panel. This study will fill the research gap. It will enrich the literature by considering the uniqueness of Islamic banks and compared it with conventional banks. Therefore, it is important to discuss the behavior of dual banking system especially in Indonesia with its majority Muslim citizen.

\section{Objective}

This study aims to analyze and obtain an understanding of how credit risks in Indonesian dual banking system responses to changes bank specific variables. In the case of internal variables, it is analyzed using a bank level data using dynamic panel data method. This study could provide some significant contributions for related stakeholders in the industry by providing empirical evidence on the key factors affecting credit risk comprehensively. By doing an analysis of bank specific variables, this study could impart greater understanding of credit risk management framework.

Knowledge about the factors affecting credit risk management is essential for numerous parties, especially with the spirit of the government and authority in Indonesia to develop Islamic economics. Some initiatives could be seen such as the establishment of National Islamic Economic and Finance Committee (KNEKS), government linked Islamic banking merger, and the instruction from Minister of Stated Owned Enterprise to move the payroll from conventional banks to Islamic banks. The knowledge is also useful for the regulator and policy maker reflected in the Basel committee's constant and ongoing effort to establish a proper guideline.

The finding from the study would be useful to formulate policy that will prevent the systemic risk. This study could also create awareness to the investors and stakeholders of Islamic bank to have a better understanding of credit risk that they are exposed to if the investment relied heavily on certain sectors. The investors will have a better information for the decision making when it comes to their investment activities. The rest of the paper is organized as follows: section 2 shortly reviews the literature regarding the determinants of banks profitability, while section 3 presents the methodological approach adopted and section 4 the results obtained. Finally, the conclusions are drawn in section 5 .

\section{LITERATURE REVIEW}

\section{Theoretical Framework}

This study determines a hypothesis from theories and previous literature review. In this subchapter, the theoretical framework is explained which are adapted from theories related to credit risk which is agency theory.

Derived from the work of Smith (1776), who suggested that managers of a company cannot be expected to pay the same amount of attention as the owner, Jensen and Meckling (1976) expand the concept in detail. The idea of an agent occurs when one party perform some specific action on the behalf of another party. When it comes to a company, the principal delegate decision making authority to the agent to monitor the management of the company. Several studies linked this theory with several problems. The action of the agent might not be in line with the interest of the principle. This could be due to different value implemented by the agent and the principle. 
According to Milson and Ward (2005), the separation of ownership and control leads to moral hazard and adverse selection. According to Junarsin and Ismiyanti (2009), the agency problem appears when the manager does not have the same goal as the shareholder. Poor financial decision with the objective of improving their own wealth is one of the forms of moral hazard derived from the agency problem. According to Jensen (1983), the problem relies on the difficulty of the principle to verify the work of the agent and the different attitude towards risk. The different attitude leads to different actions.

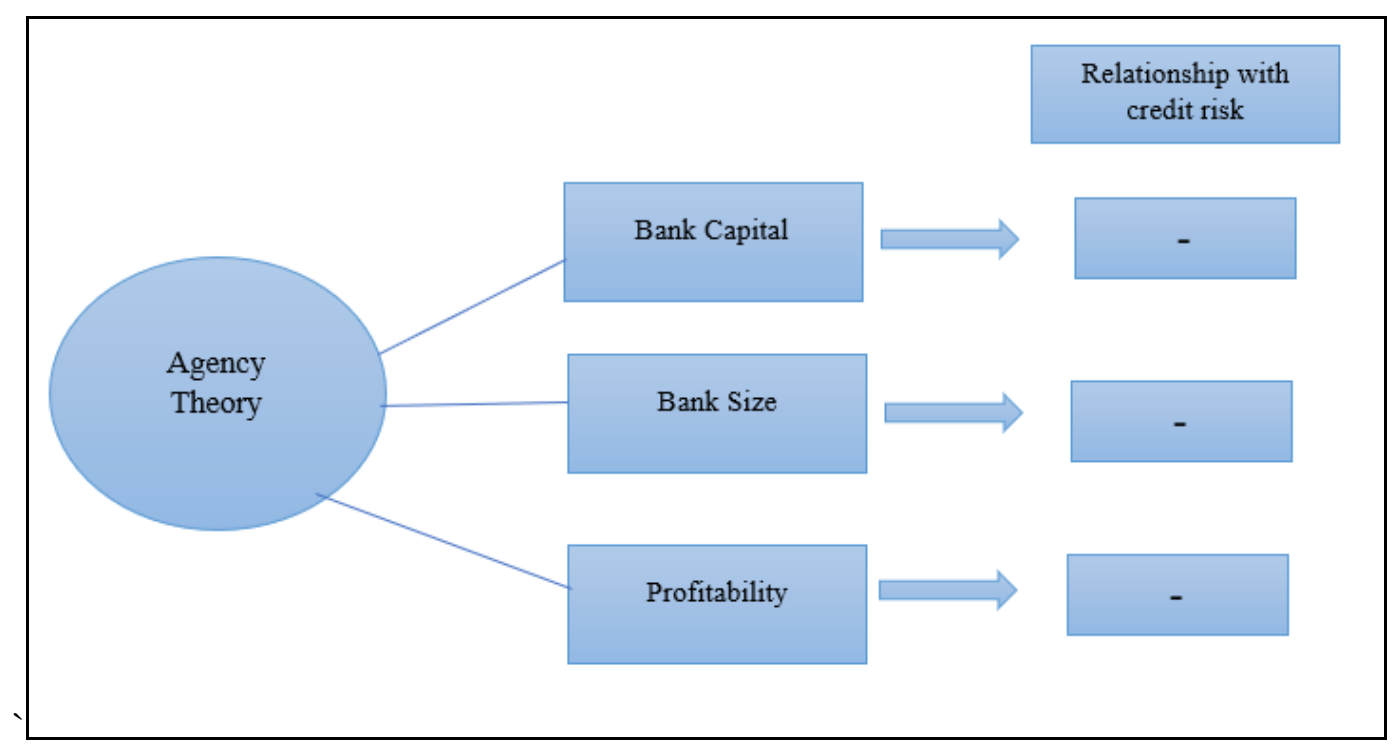

Figure 2 Agency theory related to credit risk determinants

Capital is crucial for banks to do intermediation activities. From an agency theory perspective, moral hazard that comes from the separation of ownership and control will be responded by banks in form of increasing the riskness of their loan portofolio without considering the loan quality. This will increase the credit risk in the future. Therefore, banks with adequate capital ratio should experience a lower rate of NPLs on in other word capital should have a negative relationship with credit risk.

Bank size represents the financial power of the respective bank. From an agency theory perspective, larger banks have more resources to invest in information system and apply it in various purpose such as budgeting system, reporting procedures and other things. This will benefit the bank to maintain the loan quality by practicing loan underwriting, monitoring and control. Thus, bank size is expected to have a negative relationship with credit risk. Bank profitability also determine the managers behaviour that soon will affect the credit risk. Form an agency theory perpective, the presence of agency cost reduce the profitability of the bank. However, banks with high profitability are considered to have effective credit risk management since they can manage credit portofolio and lower loan loss provision. High number of credit risk are associated with high rates of provision. Thus, profitability is expected to have a negative relationship with credit risk.

\section{Previous Literature}

There are various approaches when it comes to the definition of risk. According to Bessis (2010), risk referes to uncertauntues, potentially resulting in an adverse variation of profitability of losses. According to Howells and Bain (2008), risk refers to the probability that the actual return may differ from the expected return. In conventional finance, risk is defined as uncertainty of financial losses. When it comes to the Islamic perspective, Waemustafa and Sukri (2016) suggests risk is related to concepts like mukhatarah, gharar, maysir, al ghunm bil ghurm, al kharaj bil daman. Mukhatarah means danger and in an Islamic finance perspective, it refers to uncertainty which is related to maysir as well. The concept of al ghunm bil ghurm refers to profit lehitimated only when a party engages in real economic activities or venture. Al kharaj bil daman refers to the concept that any gain should be accompanied with liability for losses. 
The financial system nowadays is divided into two types of system which is the single banking system and the dual banking system. A single banking system refers to system where there is only on type of banking that operates in the respective country. It could be that the country only have conventional banks operating such as Hong Kong and Portugal, or only Islamic banks such as Iran and Saudi Arabia. Dual banking refers to a system where Islamic banking and conventional bank operating side by side in the country. Several countries are adopting this approach such as Indonesia and Malaysia.

In both type of approach, banks are always exposed to risk which can be categorized into three types; financial risk, business risk and operational risk. Financial risk comprise of credit risk, market risk, and liquidity risk. Business risk are the risk that arise from a bank's business environment and business model such as management and strategic risk. While operational risk refers to potential losses resulting from inadquate system, human errors and other.

This study will focus on credit risk which is one of the financial risk exposed by the banks. Credit risk are defined as the potential that a counterparty or bank borrower will fail to fullfill its obligations in accordance with agreed terms. According to Havidz and Obeng-Amposah (2020), credit risk can be categorized into two types, systematic credit risk and unsystematic credit risk. Systematic credit risk refers to variables that are not in the control of each respective banks which utilized macroeconomics variables. Once the banks are operating inside the system, it is not possible to avoid the effect. Unsystematic credit risk refers to variables are the control of the bank which are bank-specific variables.

\section{Previous Studies}

There are empirical studies that have been studying the determinants of credit risk in conventional banks. Manab, Theng, and Md-Rus (2015) study the determinants of credit risk in Malaysia. The empirical findings show that majority of the bank-specific determinants were significantly affecting bank performance. The result become even more ambiguous when the macroeconomic factors were considered. The results showed that the liquidity ratio was significant in determining credit risk before and after earnings management was adjusted. Meanwhile, the productivity ratio was significant in the unadjusted model, while the profitability ratio was significant in the adjusted model. This study provides knowledge about the effect of earning management on bankruptcy prediction.

In the case of Jordanian commercial banks, Al-Eitan and Khalid (2019) study the connection between performance and credit risk. With a panel data regression approach, the empirical findings show that $\mathrm{CR}$ has a negative and significant impact on return on assets (ROA) and return on equity (ROE). Further, the results indicated that CR (measured by the ratio of doubtful debts to total loans, nonperforming loans and loan losses to total loans) has a negative and significant impact on ROA and ROE. While, the total deposits and bank size have positive and significant impact on financial performance of these Jordanian commercial banks.

In another study, Shkodra and Ismajli (2017) study the determinants of credit risk in Kosovo. The empirical findings show that a significant relationship exists between credit risk and the following variables, profitability, inefficiency, loans to deposit ratio, credit growth and deposit rate, while variables of solvency and credit rate are not statistically significant in terms of credit risk.

There are also empirical studies that have been studying the determinants of credit risk in Islamic banks. In the case of Malaysia, the study of Adebola, Yusoff and Dahalan (2011) shows that the findings indicate two long run relationship among the variables and note that interest rate has significant positive long run impact on NPLs. Industrial production index turns out with a positive but insignificant sign. This reflects the popular believe that Islamic banking system in Malaysia is not fully motivated by profit and loss mechanism, as the impact of interest rate is stronger relative to productivity. Producer price index appears to have negative and significant impact on NPLs. 
In addition to that, Wiryono and Effendi (2018) study the credit risk determinants of Islamic banks in Indonesia. The result finds the results support the hypothesis that the size of the bank is influencing positively and significantly the credit risk. Other variables tested were financing expansion, financing quality, GDP and inflation which have been proven to influence negatively and significantly the credit risk.

Alongside studies focusing in the determinant variables of Islamic and conventional banks separately, there are also some studies focusing on the determinants of credit risk in Islamic banks and conventional banks comparatively. Akram and Rahman (2018) study the credit risk management of Islamic and conventional banks in Pakistan. The results show that loan quality (LQ) has a positive and significant impact on CRM for both IBs and CBs. Asset quality (AQ), on the other hand, has a negative impact on CRM in the case of IBs, but has a significantly positive relation with CRM in the case of CBs. The impact of 16 ratios measuring LQ and AQ have also been individually checked on $\mathrm{CRM}$, by making use of a regression model using a dummy variable of financial crises for robust comparison among Cbs and IBs. The model proved significant, and CRM performance of IBs was observed to be better than that of CBs. Moreover, the mean average value of financial ratios used as a measuring tool for these variables shows that the CRM performance of IBs operating in Pakistan was better than that of $\mathrm{CBs}$ over the period of the study.

Waemustafa and Sukri (2015) study the credit risk determinants of Islamic and conventional banks in Malaysia. Findings from this research contribute in enriching and enhance literature on risk management of Islamic and conventional banks. The problem of credit risk regarding regulatory requirement will decrease and this will give banks to increase their profitability and improve their financial performance.

Ferhi (2017) study the credit risk determinants of Islamic and conventional banks in MENA region. The results showed that the conventional model has a higher credit risk than the Islamic one. These results also showed that the larger an Islamic bank is, the higher its credit risk will be to get closer to that of conventional banks.

There is a literature gap in evaluating the credit risk determinant of both type of bank in Indonesia to be filled by this study. It is proofed by the non-existence of this topic examined using a dynamic panel method found by the author. The existing literatures suggest that there are various result relating to the determinant of credit risk. The selection of the dependent and the independent variable is also various, enrich the explanation of this topic even further.

\section{Conceptual Framework}

Beside the systemic credit risks which is proxied by the macroeconomic variables, credit risk is also determined unsystematic represented by the bank specific variables. Following the same vein as Ferhi (2017), this research paper used NPL to total loan to measure credit risk in Indonesian dual banking. Therefore, the research paper used several ratios in order to measure credit risk.

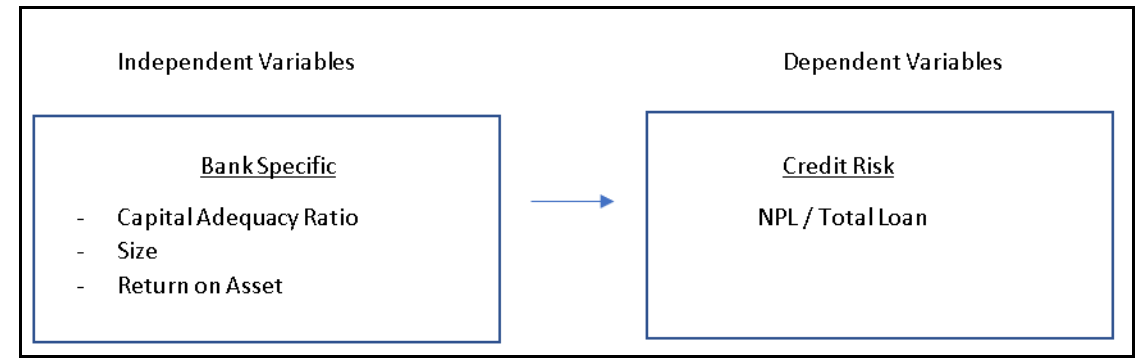

Source: Ferhi, 2017.

Figure 3 Conceptual framework of research model 
As we can see in the Figure 3, credit risk is used as the dependent variable in this study. It shows the percentage of non-performing loans to total loans. NPL/Total Loan was treated as measure of financial performance in the research. Numerous papers used NPL/Total Loan as to assess the credit risk such as Sukmana (2017). The first internal variable is capital adequacy ratio. This ratio measures the financial strength of a bank by dividing capital to asset. The ratio which also known as capital risk-weighted asset ratio is used to protect depositors and promote the stability and efficiency of financial system. Numerous papers used capital strength as to assess the credit risk such as Mendoza and Rivera (2017) also Havidz and Obeng-Amposah (2020). In this research, capital strength is expected to have a positive impact on the credit risk.

The next internal variable is natural log of total asset. Size is used as a proxy in order to capture the cost advantage associated with size. Usually, the impact of bank size on credit risk is expected to be positive. Numerous papers used size ratio as to assess the profitability performance such as Ali, Zulkhibri and Kishwar (2019). Under the 'too big to fail' theory, big banks knew that the government would rescue them when a crisis appears due to various reasons and leads to bankruptcy. This caused the banks to channel the credit without any proper prudency which could be categorized as a moral hazard action. Therefore, asset is expected to be positive.

After that, profitability is used as another independent variable. Return on asset is used as the proxy of profitability in this study. Ali and Puah (2018) is one of the previous studies that used profitability to assess the determinants of credit risk. In their study, they found out that the relationship between credit risk and profitability is negative. This is in line with the result of Mendoza and Rivera (2017). Therefore, ROA is expected to be negative in this study.

\section{METHOD}

\section{Data}

The data consists of eight Islamic banks and thirty three conventional banks from 2011 until 2020 (see Appendix A). The study excludes the rural banks despite the presence of Islamic rural banks. In order to be included, there are two conditions; the bank must be operating in Indonesia and should have complete data which will be used as the variables within the period of study from 2011 to 2020 . The data for bank specific variable is mainly taken from the annual report in each bank or the Financial Service Authority.

Table 1 Data and variables

\begin{tabular}{|c|c|c|}
\hline Variables & Description & Source \\
\hline \multicolumn{3}{|c|}{ Dependent variables } \\
\hline NPL & Non-performing loans/Gross Loans & Annual Report/OJK \\
\hline \multicolumn{3}{|c|}{ Independent (Internal) } \\
\hline SIZE & Total Asset & Annual Report/OJK \\
\hline ROA & Return on Asset & Annual Report/OJK \\
\hline CAR & Capital Adequacy Ratio & Annual Report/OJK \\
\hline Dummy & Equal 1 if Bank is Islamic or 0 Otherwise & \\
\hline
\end{tabular}

\section{Method}

In econometrics, there are three types of data: cross section, time series and panel data. Panel data is a combination of time series data and cross section data. It can be said that panel data is the same parameters observed in the cross-section data but in certain period. This study is using dynamic panel data as the method to achieve the research objective. According to Gujarati (2003), the difference of panel data regression can be seen in the double subscript in every variable. This study will test three different methods. According to Havidz and Obeng-Amposah (2020), the advantage of panel data analysis lies on the better efficiency forecast individual outcomes in the model. 
First, fixed effect model/random effect model will be utilized to control unobserved heterogeneity between the banks. The equation of static panel data is written below:

$$
\text { Credit Risk }_{i t}=\beta_{1 i}+\beta_{2} X_{2 i t}+\beta_{3} X_{3 i t}+u_{i t}
$$

However, the fixed effect model approach becomes more consistent with larger data basis thus it might raise the possibility of dynamic panel bias. To address this problem this study would try to add lagged value of bank's credit risk into the right-hand side of the equation as follows:

$$
\text { Credit Risk }_{i t}=\beta_{1 i}+\beta_{2} \text { Credit Risk }_{i, t-1}+\beta_{3} X_{3 i t}+u_{i t}
$$

The second approach (2) could create another problem which makes the lagged dependent variable correlate to the fixed effect error term. To address this situation, applying difference GMM would be a valid solution. Difference GMM application could fix fixed effect problem by transforming the first order difference and use lagged dependent variable at the right-hand side equation model as instruments (Arellano and Bond, 1991). Therefore, the equation of the model will be express as follow:

$$
\text { Credit Risk }_{i t}=\beta_{1 i}+\beta_{2} \text { Credit Risk }_{i, t-2}+\beta_{3} X_{3 i t}+u_{i t}
$$

The third approach (3) could still create another problem which makes the lagged dependent variable correlate to the fixed effect error term. Data set with persistence could have lower precision estimation because it causes the lagged level to be less correlated with its following changes thus it becomes weak instruments (Blundell and Bond, 1998). To obtain better result from the different GMM, system GMM will also be applied by using forward orthogonal deviations propose by (Arrelano and Bover , 1995). The use of system GMM could improve efficiency and transform the instrument variable to be uncorrelated with fixed effect.

\section{Model Development}

The main approach to fit the model used in this study is the dynamic panel data. To reflect the variables described in table 1 , the regression is formulated as follow:

$$
\begin{aligned}
& \text { Credit Risk }_{i t}=\beta_{1 i}+\beta_{2} \text { Credit Risk }_{i, t-2}+\beta_{3} \text { ROA }_{3 i t}+\beta_{4} \text { SIZE }_{i t}+\beta_{5} \text { CAR }_{i t}+\beta_{6} \text { DUMMY }+ \\
& u_{i t}
\end{aligned}
$$

$$
\text { Credit Risk }_{i t}=\beta_{1 i}+\beta_{2} \text { Credit Risk }_{i, t-2}+\beta_{3} \text { ROA }_{3 i t}+\beta_{4} S I Z E_{i t}+\beta_{5} \text { CAR }_{i t}+u_{i t}
$$

In the fourth equation, relationship between the dependent variables, Credit Risk (NPL/NPF) with the independent variables are tested in the combined model. In the combined model (1), a dummy variable is used to separate Islamic banks and Conventional banks, where dummy $=1$ refers to Islamic Banks and dummy $=0$ refers to conventional banks. In the separated model (2), the data is separated based on the type of the bank. There will be a specific model for Islamic banks and another specific model for Conventional banks. These models are established to test the robustness of the model. With these models, we also analyze whether the credit risk determinants in Islamic banks are different compared to the credit risk determinants in Conventional banks. Because of the separated data used in the model, a dummy variable is no longer needed.

In order to assess the robustness of the model, author is using an additional method. Beside assessing the robustness of the model by the usual way; looking into the instrument validity with Sargan test, the consistence represented in the $2^{\text {nd }}$ ordo of autocorrelation test, and the unbiased test by comparing the result with the result from PLS and FEM model, separating data is also used. In line with the objective of the study, the model is divided into two types of regression: conventional and Islamic banking regression. Both type of model is separated even deeper; either Islamic banking or 
conventional banking regression is separated according to periods and type of ownership. The main model can be stated as a robust model when the result is consistent compared to the divided models.

\section{RESULTS AND DISCUSSION}

\section{Results}

The objective of this section is to give an overview analysis for the study in terms of scope of the data and variables. Table 2 summarizes the descriptive statistics of the variables, illustrated by its mean, median, minimum, maximum, and standard deviation values. In that table, the figures of the variables are expressed in forms of ratios, which will narrow the dispersion that could happen due to the huge difference in assets and loans (financing) banks. However, it can't derive a concrete conclusion solely based on descriptive statistics. Thus, in this case, factors such as credit risk is subject to many factors such as size, the bank's risk strategy (adverse risk or otherwise). Therefore, this part will be limited to describing the data by summarizing, organizing, and simplifying it. Thus, it pictures the data on the data used in this study clearly.

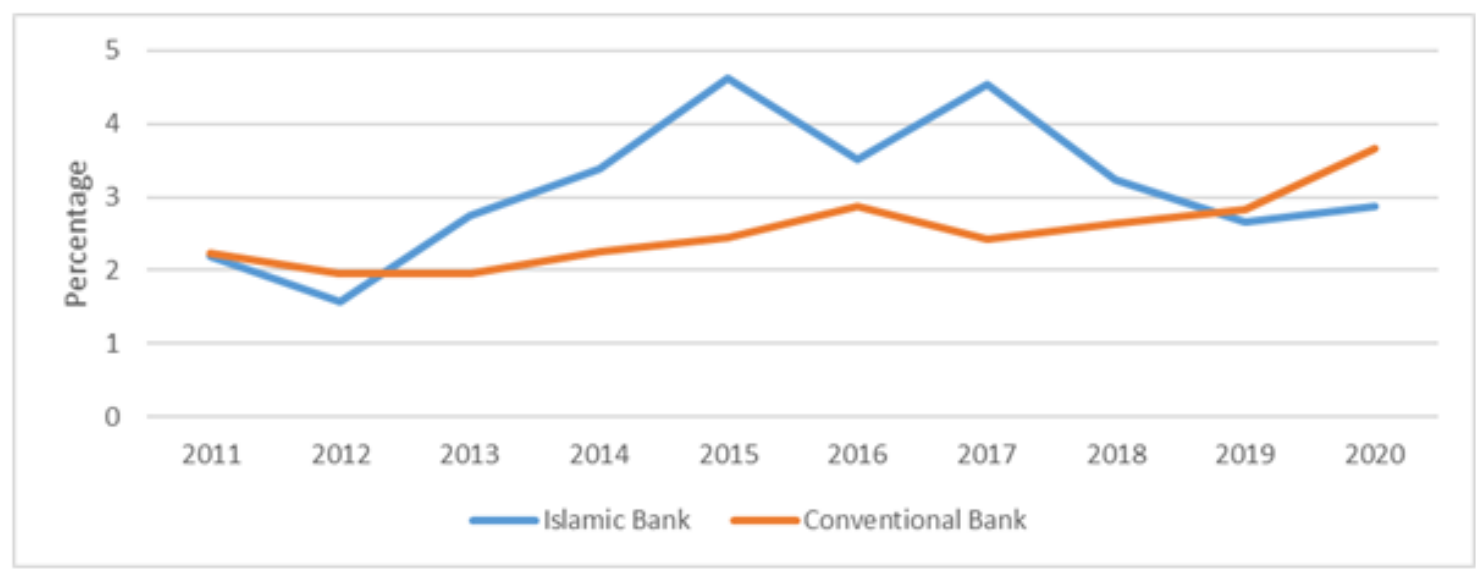

Figure 4 Average non-performing loan/non-performing financing in Indonesian banks 2011-2020

The dominance of conventional banks in Indonesia which is seen in the total asset figure can also be seen in the Non-Performing Loan/Non-Performing Financing figure. The credit risk figure of Islamic banks is higher than the conventional banks in almost every year. If we look closely, there is a trend captured in the credit risk in the crisis. In 2011-2012 where the debt crisis in Europe was still happening, the credit risk level of Islamic bank is lower than conventional banks. Same result captured in 2019-2020 where the pandemic crisis just started, Islamic banking credit risk is better than conventional banking. However, in 2013-2018 where there is no crisis, the credit risk of conventional banks is better than the credit risk of Islamic banks. This indicates that when the economic situation is worse, Islamic bank perform better than conventional banks vice versa.

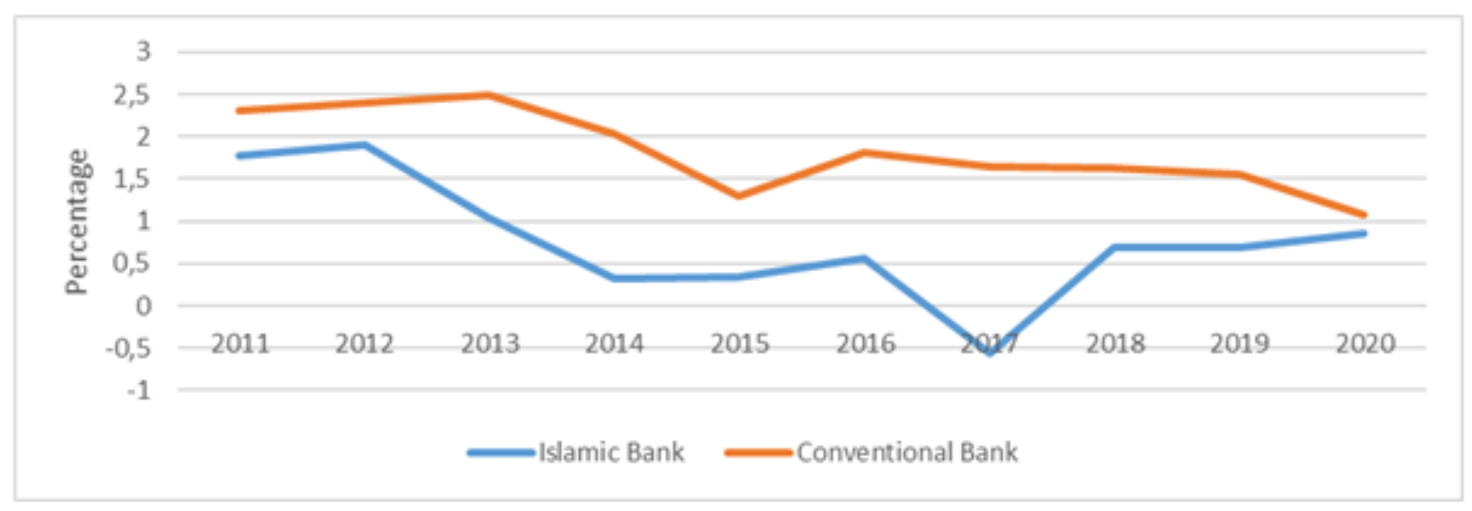

Figure 5 Average return on asset in Indonesian bank 2011-2020 
The trend captured in the credit risk figure is in line with the return on asset figure. The dominance of conventional banks in Indonesia is obviously presented in the ROA figure. There is no year that Islamic bank outperform conventional banks in terms of ROA. Islamic banking are still young compared to conventional banks in Indonesia. The young age of Islamic banks caused disadvantages in terms of operational compared to conventional banks. Fatwas about derivatives unable them to use all the instruments in the financial market. The limited option caused the profitability lower than conventional banks.

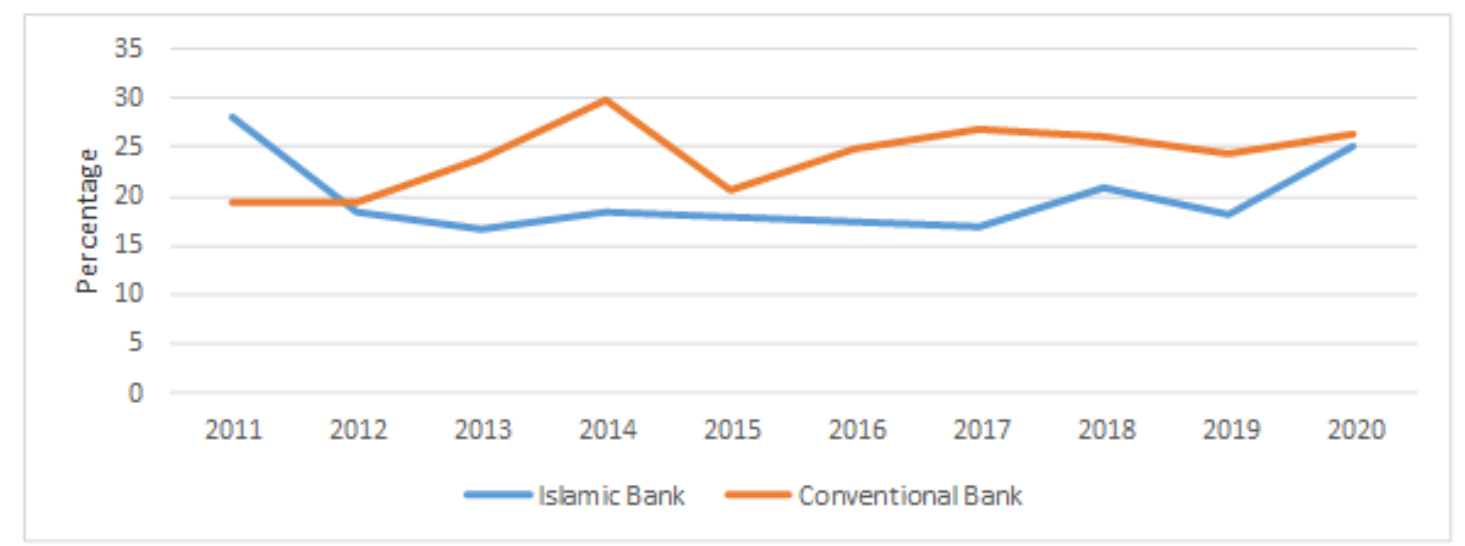

Figure 6 Average capital adequacy ratio in Indonesian bank 2011-2020

Table 2 Summary of regression using the whole data, conventional and Islamic banking 2011-2020

\begin{tabular}{lcccc}
\hline \multicolumn{1}{c}{ Variable } & $\begin{array}{c}\text { Short-run } \\
\text { Coefficient }\end{array}$ & Prob & $\begin{array}{c}\text { Long-run } \\
\text { Coefficient }\end{array}$ & $\begin{array}{c}\text { Convergence } \\
\text { Rate }\end{array}$ \\
\hline Lag (NPF) & 0.4034708 & $7.058 \mathrm{e}-07 * * *$ & N/A & 0.9076511 \\
ROA & -0.4933158 & $0.0001071^{* * *}$ & -0.8269768 & N/A \\
LNASSET & 0.2122818 & $1.559 \mathrm{e}-07 * * *$ & 0.3558616 & N/A \\
CAR & 0.0067802 & 0.4150764 & 0.01136616 & N/A \\
DUMMY & 0.2083648 & 0.4620307 & N/A & N/A \\
\hline
\end{tabular}

Note: * significant at $10 \%, * *$ significant at $5 \%, * * *$ significant at $1 \%$

The combined regression model is categorized as a robust model due to several test. The P-value of the Sargan test is 0.73192, which means that the instruments used in the model is valid. The P-value of the second ordo of the autocorrelation is also insignificant which means that the model is consistent. The coefficient of lag dependent variable in the system GMM model is also smaller than the coefficient of lag dependent in the PLS panel data model, but bigger than the coefficient of lag dependent in the FEM panel data model. This also means that the model is unbiased. When it comes to the variables, majority independent variables are affecting the credit risk significantly. Only profitability is in line with the hypothesis in the combined model. However, the dummy variable that distinguished Islamic bank and conventional is not significant. To investigate the dummy result even further, the author split the model into two models based on the period.

Table 3 Summary of regression using the whole data, conventional and Islamic banking 2011-2015 and 2016-2020

\begin{tabular}{ccccc}
\hline & \multicolumn{2}{c}{$\mathbf{2 0 1 1 - 2 0 1 5}$} & \multicolumn{2}{c}{$\mathbf{2 0 1 6 - 2 0 2 0}$} \\
\hline Variable & Coefficient & Prob & Coefficient & Prob \\
\hline Lag (NPF) & 0.5451489 & $3.874 \mathrm{e}-15 * * *$ & 0.110534 & 0.1194 \\
ROA & -0.2775838 & $0.005671 * *$ & -0.729948 & $1.102 \mathrm{e}-07 * * *$ \\
LNASSET & 0.1481097 & $5.758 \mathrm{e}-08 * * *$ & 0.288204 & $4.547 \mathrm{e}-07 * * *$ \\
CAR & -0.0018448 & 0.754344 & 0.019634 & 0.4346 \\
DUMMY & 0.7397877 & $0.027750 *$ & 0.071791 & 0.8687 \\
\hline
\end{tabular}

Note: $*$ significant at $10 \%, * *$ significant at $5 \%, * * *$ significant at $1 \%$ 
The split model explains that the dummy variable in the 2011-2015 period is not significant while the dummy variable in the 2016-2020 period is significant (see Appendix). This could mean that there is a different behavior between Islamic bank and conventional banks in credit risk, especially when we refer to the first period. In general, the result of other independent variables is consistent with lag dependent, profitability and size significantly affect the credit risk. To test the robustness even deeper, the author is splitting the model based on the type of the bank.

Table 4 Summary of conventional banks regression 2011-2020

\begin{tabular}{lcccc}
\hline Variable & Coefficient & Std. Error & Z-Value & Prob \\
\hline Lag (NPF) & 0.4850973 & 0.1164328 & 4.1663 & $3.095 \mathrm{e}-05 * * *$ \\
ROA & -0.3133749 & 0.1248404 & -2.5102 & $0.012066^{*}$ \\
LNASSET & 0.1599004 & 0.0505450 & 3.1635 & $0.001559^{* *}$ \\
CAR & 0.0085686 & 0.0071360 & 1.2008 & 0.229842 \\
\hline
\end{tabular}

Note: * significant at $10 \%, * *$ significant at $5 \%, * * *$ significant at $1 \%$

Table 5 Summary of conventional banks regression 2011-2015 and 2016-2020

\begin{tabular}{lcccc}
\hline & \multicolumn{2}{c}{$\mathbf{2 0 1 1 - 2 0 1 5}$} & \multicolumn{2}{c}{$\mathbf{2 0 1 6 - 2 0 2 0}$} \\
\hline Variable & Coefficient & Prob & Coefficient & Prob \\
\hline Lag (NPF) & $4.5075 \mathrm{e}-01$ & $5.519 \mathrm{e}-05 * * *$ & 0.318785 & 0.1268 \\
ROA & $-1.8264 \mathrm{e}-01$ & $0.08898 *$ & -0.478268 & 0.1424 \\
LNASSET & $1.4355 \mathrm{e}-01$ & $1.225 \mathrm{e}-05 * * *$ & 0.196301 & 0.1208 \\
CAR & $3.7904 \mathrm{e}-05$ & 0.99524 & 0.022175 & 0.3473 \\
\hline
\end{tabular}

Table 6 Summary of state-owned and private-owned conventional banks regression

\begin{tabular}{lcccc}
\hline & \multicolumn{2}{c}{ State-Owned } & \multicolumn{2}{c}{ Private-Owned } \\
\hline Variable & Coefficient & Prob & Coefficient & Prob \\
\hline Lag (NPF) & 0.3866997 & $2.2 \mathrm{e}-16^{* * *}$ & 0.4468721 & $1.872 \mathrm{e}-05 * * *$ \\
ROA & -0.5309333 & $7.599 \mathrm{e}-09 * * *$ & -0.3034048 & $0.021492 *$ \\
LNASSET & 0.2328108 & $2.2 \mathrm{e}-16 * * *$ & 0.1696397 & $0.000175 * * *$ \\
CAR & 0.0014939 & 0.8507 & 0.0070974 & 0.328412 \\
\hline
\end{tabular}

The result of the conventional bank regression is consistent with the combined regression where the lag dependent and size are affecting the credit risk significantly in a positive relationship. The profitability is also affecting the credit risk significantly, but in a negative relationship. While the capital adequacy ratio is not affecting the credit risk significantly according to this model. When it comes to the model divided according to the period and the ownership of bank, the result remains consistent. While the result from the model divided according to the ownership of the bank is consistent in terms of significance and positive/negative relationship, in the model divided according to the period the positive/negative relationship is consistent.

Table 7 Summary of Islamic banks regression

\begin{tabular}{lcccc}
\hline Variable & Coefficient & Std. Error & Z-Value & Prob \\
\hline Lag (NPF) & 0.429000 & 0.106798 & 4.0169 & $5.897 \mathrm{e}-05 * * *$ \\
ROA & -0.824196 & 0.085594 & -9.6291 & $2.2 \mathrm{e}-16^{* * *}$ \\
LNASSET & 0.322801 & 0.048449 & 6.6627 & $2.688 \mathrm{e}-11^{* * *}$ \\
CAR & -0.030389 & 0.021119 & -1.4390 & 0.1502 \\
\hline
\end{tabular}

Note: $*$ significant at $10 \%, * *$ significant at $5 \%, * * *$ significant at $1 \%$ 
Table 8 Summary of Islamic banks regression 2011-2015 and 2016-2020

\begin{tabular}{lllll}
\hline & \multicolumn{2}{c}{ 2011-2015 } & \multicolumn{2}{c}{ 2016-2020 } \\
\hline Variable & Coefficient & Prob & Coefficient & Prob \\
\hline Lag (NPF) & 0.7914078 & $1.184 \mathrm{e}-07 * * *$ & 0.285138 & $0.001677 * * *$ \\
ROA & -0.7892797 & $0.001153 * * *$ & -0.865564 & $2.2 \mathrm{e}-16 * * *$ \\
LNASSET & 0.2195919 & $0.005238 * * *$ & 0.327828 & $1.13 \mathrm{e}-08 * * *$ \\
CAR & -0.0067993 & 0.788878 & -0.022841 & 0.363217 \\
\hline
\end{tabular}

Note: $*$ significant at $10 \%, * *$ significant at $5 \%, * * *$ significant at $1 \%$

Table 9 Summary of state-owned and private-owned Islamic banks regression

\begin{tabular}{lcccc}
\hline & \multicolumn{2}{c}{ State-Owned } & \multicolumn{2}{c}{ Private-Owned } \\
\hline Variable & Coefficient & Prob & Coefficient & Prob \\
\hline Lag (NPF) & 0.4468721 & $1.872 \mathrm{e}-05 * * *$ & 0.439186 & $0.0004367 * * *$ \\
ROA & -0.3034048 & $0.021492 *$ & -0.795675 & $2.2 \mathrm{e}-16 * * *$ \\
LNASSET & 0.1696397 & $0.000175 * *$ & 0.353275 & $1.485 \mathrm{e}-07 * * *$ \\
CAR & 0.0070974 & 0.328412 & -0.043915 & 0.1170493 \\
\hline
\end{tabular}

Note: * significant at $10 \%, * *$ significant at $5 \%$, *** significant at $1 \%$

The result of the Islamic bank regression is also consistent with the combined regression where the lag dependent and size are affecting the credit risk significantly in a positive relationship. The profitability is also affecting the credit risk significantly, but in a negative relationship. While the capital adequacy ratio is not affecting the credit risk significantly according to this model. When it comes to the model divided according to the period and the ownership of bank, the result remains consistent. The difference from the divided conventional bank regression model, the divided Islamic banking regression remain consistent in every single way in terms of significance and positive/negative relationship.

\section{Analysis}

Based on the result of the combined model, there are some independent variables that significantly affect credit risk. Lag dependent is one of the variables that significantly affects the credit risk. Due to the characteristics of dynamic panel data where lag dependent can be found as an independent variable, we are able to gain the information about the convergence rate from the dependent variable among the cross section. We can also calculate the short-term and long-term influence from each independent variable. In every year, gap reduction of credit risk among the banks is $90.76 \%$ with the assumption that there is no shock. Profitability significantly affects credit risk with a negative relationship. This means that the credit risk will decrease $0.49 \%$ if the profitability increases $1 \%$. This is in line with the result found in the study of Mendoza and Rivera (2017).

Size significantly affects credit risk with a positive relationship. This means that the credit risk will increase if the $0.21 \%$ size increases $1 \%$. This could be interpreted that the 'too big to fail' theory might be accepted in this study. When it comes to the dummy variable, it can be said that the type of bank doesn't play a significant role in determining the credit risk. in other word, there is no difference between Islamic bank and conventional banks in terms of credit risk. When we split the combined model into 2011-2015 and 2016-2020 model, there is a difference in terms of the significance of dummy variable where the dummy variable did not affect the credit risk significantly based on the result on table 4. Crisis could play a role on the result. A combination of the USA-China trade war and the beginning of the pandemic happened in the 2016-2020 period.

To analyze the crisis effect deeper, we compare the result of conventional banking model 2016-2020 in table 6 and Islamic banking model 2016-2020 in Table 9. While there is no independent variable that significantly affect the credit risk in the conventional banking model 2016-2020, three out of four independent variables affect credit risk significantly in the Islamic banking model 2016-2020. This could be interpreted that there is a different behavior in the lending/financing strategy between 
Islamic banking and conventional banking in the crisis period. The related phenomenon to describe the result is the credit crunch in the conventional banking. Credit crunch is defined as a decline in the supply of credit that is abnormally large for a given stage of the business cycle.

According to Holmberg (2011), during a crunch/crisis, seemingly eligible borrowers find it hard to get credit under reasonable terms, forcing firms that rely on external capital to a halt. This is because banks tend to play safe by avoiding the disbursement of credit and focusing on derivatives. It is well known that banks use derivatives to manage risk by complementing traditional lending activity (Brewer, Minton and Moser, 2000). Especially in the crisis, banks judge liability structures subjectively that cause drops in the supply of credit may occur when corporate debt reaches some unforeseen threshold (Holmberg, 2011).

This strategy used by conventional banking is not suitable for Islamic banking as they are not allowed to do speculative activities. Since conventional banks have started their operation for a long time ago, their ecosystem is sophisticated. With the young age, Islamic banks are still in the early stages including the supporting system such as Islamic capital market. Therefore, they are focusing on traditional banking activities including in hard times such as crisis periods. This could be a positive sign for Islamic banking as they are operating in real economic activity which is the characteristics of Islamic banking as the biggest part of Islamic economy. They could be the hero that saves the economy from a recession with that. However, that characteristic makes Islamic banking riskier than conventional banking as they are more exposed to risk.

\section{CONCLUSION}

\section{Conclusion}

The empirical result in the combined model, profitability significantly affects credit risk with a negative relationship. Size also significantly affects credit risk with a positive relationship. This could be interpreted that the 'too big to fail' theory might be accepted in this study. When it comes to the dummy variable, it can be said that the type of bank doesn't play a significant role in determining the credit risk. In other word, there is no difference between Islamic bank and conventional banks in terms of credit risk. The conventional banking model 2016-2020 reveals that here is no independent variable that significantly affect the credit risk while majority independent variables affect credit risk significantly in the Islamic banking model 2016-2020. This is because banks tend to play safe by avoiding the disbursement of credit and focusing on derivatives.

\section{Recommendation}

The government recently merger three state owned Islamic bank in order to strengthen the capital position of the bank. Regulation for the government bodies to put shift their account from conventional banking account to Islamic banking account has also been done either in the national level or in the state level. However, low literacy is still the problem. Since people are still unaware with Islamic banking and finance, socialization about it needs to be done massively. Specific socialization such as the patriotic histories in the past mixed with updated issues such as digital transformation is a way to promote the industry.

It is well known that banks use derivatives to manage risk by complementing traditional lending activity. However, this strategy is not suitable for Islamic banking as they are not allowed to do speculative activities. Islamic banking are still focusing on traditional banking activity. This could be a positive sign for Islamic banking as they are operating in real economic activity. However, that characteristic makes Islamic banking riskier than conventional banking as they are more exposed to risk. Islamic Economic and Finance National Committee (KNEKS) with the working group consist of related authorities such as the central bank, financial service authority, and other authorities to solve this related problem. A sophisticated and complete Islamic capital market with shariah compliant 
derivatives needs to be established in order to complement Islamic banking for the purpose of risk management. The steps of Malaysian government for Islamic banking could be taken as a consideration. Islamic banking in Malaysia is now focusing on investment account platform where profit-loss contracts are encouraged to be used as their characteristics that suits investment activities. This kind of platform could be the answer for risk management difficulties. For the further research, the element of pandemic should be inserted inside the model. Analyzing the credit risk before and after the pandemic could be one of the ideas for the next research.

\section{REFERENCES}

Adebola, S. S., Wan Yusoff, W. S., \& Dahalanc, J. (2011). An ARDL approach to the determinants of non performing loans in Islamic banking system in malaysia. Kuwait Chapter of Arabian Journal of Business and Management Review, 1(2), 20-30.

Akram, H. \& Rahman, K. u. (2018). Credit risk management A comparative study of Islamic banks and conventional banks in Pakistan. ISRA International Journal of Islamic Finance, 10(2), 185205.

Al-Eitan, G. N. \& Bani-Khalid, T. O. (2019). Credit risk and financial performance of the Jordanian commercial banks: a panel data analysis. Academy of Accounting and Financial Studies Journal, 23(5), 1-13.

Ali \& Puah. (2018). The internal determinants of bank profitability and stability: An insight from banking sector of Pakistan. Management Research Review, 2040(8269).

Ali, A., Zulkhibri, M. \& Kishwar, T. (2019). Credit risk, bank performance, and Islamic banking: Evidence from pakistan. Islamic Finance, Risk-Sharing and Macroeconomic Stability, 171-189. doi:doi:10.1007/978-3-030-05225-6_9.

Arellano, M. \& Bond, S. (1991). Some tests of specification for panel data: Monte Carlo evidence and an application to employment equations. The Review of Economic Studies, 58(2), 277-297.

Arrelano, M. \& Bover, O. (1995). Another look at the instrumental variable estimation of errorcomponents models. Journal of Econometrics, 68(1), 29-51.

Blundell, R., \& Bond, S. (1998). Initial conditions and moment restrictions in dynamic panel data models. Journal of econometrics, 87(1), 115-143.

Brewer, E., Minton, B. A. \& Moser, J. T. (2000). Interest rate derivatives and bank lending. Journal of Banking \& Finance, 24(3), 353-379.

Candera, M., Muslimin, A. \& Permatasari Dina. (2021). Banking financial performance before and during the Covid 19 pandemic in Indonesia - Analysis of comparison between Islamic and conventional Banking. IT in Industry, 9(1), 976-986.

Fakhri, U. N. \& Darmawan, A. (2021). Comparison of Islamic and conventional banking financial performance during the covid-19 period. International Journal of Islamic Economics and Finance, 4(SI)(Special Issue), 19-40.

Ferhi, A. (2017). Credit risk and banking stability: A comparative study between Islamic and conventional banks. Intellectual Property Rights: Open Access, 5(3), 1-7.

Gujarati, D. N. (2003). Basic Econometrics. New York (US): McGraw-Hill Higher Education.

Haryono, Y. (2016). Credit Risk Management Practices and Their Determinants: An Investigation of the Indonesian Islamic Banks. Kuala Lumpur (MY), IIUM.

Havidz \& Obeng-Amposah. (2020). Indonesian banking industry specific and macroeconomic determinant of credit risk. International Journal of Advanced Engineering Research and Science (IJAERS), 7(1).

Holmberg, U. (2011). Banking and the determinants of credit crunches. Research Papers in Economics, 1-23.

Majid, M. A. \& Ulina, S. (2020). Does the 2008 global financial crisis matter for the determinants of conventional and Islamic banking performances in indonesia. Jurnal Ekonomi \& Keuangan Islam, 6(2), 77-90.

Manab, N. A., Theng, N. Y. \& Md Rus, R. (2015). The determinants of credit risk in Malaysia. Procedia - Social and Behavioral Sciences, 1772, 301-308. 
Masud, S. (2009). Could Islamic finance have prevented the global economic crisis?. Global Economic Finance Centre.

Mendoza, R.R. \& Rivera, J. P. R. (2017). The effect of credit risk and capital adequacy on the profitability of rural banks in the philippines. Scientific Annals of Economic and Business, 64(1), 69-83.

[OJK] Otoritas Jasa Keuangan. (2020). Statistik Perbankan Syariah. Perizinan dan Informasi Perbankan. Jakarta (ID), Otoritas Jasa Keuangan.

[OJK] Otoritas Jasa Keuangan. (2013-2019). Statistik Perbankan Syariah. Jakarta (ID), Otoritas Jasa Keuangan.

Shkodra, J. \& Ismajli, H. (2017). Determinants of the credit risk in developing countries: A case of Kosovo banking sector. Banks and Bank Systems, 12(4).

Sukmana, R. (2017). Determinants of credit and financing risk: Evidence of dual banking system in Indonesia. Journal of Islamic Finance, 3(2), 98-112. doi:http: //dx.doi.org/10.12785/jifs/030204.

Waemustafa, W., \& Sukri, S. (2015). Bank specific and macroeconomics dynamic determinants of credit risk in Islamic banks and conventional banks. International Journal of Economics and Financial Issues, 5(2), 476-481.

Wiryono, S. K. \& Effendi, K. A. (2018). Islamic bank credit risk: Macroeconomic and bank specific factors. European Research Studies Journal, 21(3), 53-62.

Zahra, S. F., Ascarya \& Huda, N. (2018). Stanility measurement of dual banking system in Indonesia: Markov switching approach. Al-Iqtishad: Journal of Islamic Economics, 10(1), 25-52.

Zarrouk, H., Jedidia, K. B. \& Moualhi, M. (2016). Is Islamic bank profitability driven by same forces asconventional banks? International Journal of Islamic and Middle Eastern Finance and Management, 9(1), 46-66. 